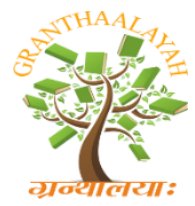

INTERNATIONAL JOURNAL OF RESEARCH GRANTHAALAYAH

A knowledge Repository

Science

\title{
LANDUSE AND LANDCOVER CHANGES AND THEIR GEO- ENVIRONMENTAL IMPACTS IN NACHOLE UPAZILA UNDER CHAPAI-NAWABGANG DISTRICT OF BANGLADESH: A RS AND GIS APPROACH
}

\author{
Md. Shahjahan Ali 1, S. M. Mizanur Rahman 1, Abu Mohammad 1, Shyamal Baran Saha 1, \\ S.A.M. Arif-Ul-Haque ${ }^{1}$, Ms. Nazma ${ }^{2}$, Ashfaque Ahmed ${ }^{3}$ \\ ${ }^{1}$ Bangladesh Space Research and Remote Sensing Organization (SPARRSO, Agargaon, Dhaka- \\ 1207, Bangladesh \\ ${ }^{2}$ Local Government Engineering Department \\ ${ }^{3}$ Ecology and Environment Laboratory, Department of Botany, University of Dhaka, Dhaka-
} 1000

\begin{abstract}
This study has been carried out to distinguish the changing pattern of land use and its geoenvironmental impacts on of Nachole Upazila of Chapai Nawabganj District in the Division of Rajshahi, Bangladesh. This study investigated the changes in land-use and land cover of Nachole Upazila. Satellite images were analyzed to detect changes in land use and land-cover in the last 34 years in Barind tract of Nachole Upazila of Bangladesh. The Increase of vegetation cover and changes in land use pattern has been investigated using remote sensing satellite data. Digital analysis found the significant changes, particularly on the burned land that has been transformed mostly into vegetation (Rahman \& Rahman, 2007). The study found that during the last 34 years (1983-2016) 26,484.9 hectares of the bare soil area has been converted into Garden and 5306.4 hectares to settlement. The main objectives of the study were to find out the landuse changing patterns and its Geo-environmental impacts due to these changes on Nachole Upazilla of Chapai Nawabgonj District in the Division of Rajshahi, Bangladesh.
\end{abstract}

Keywords: Landuse; Nachole; Environmental Impacts; Chapai-Nawabgang.

Cite This Article: Md. Shahjahan Ali, S. M. Mizanur Rahman, Abu Mohammad, Shyamal Baran Saha, S.A.M. Arif-Ul-Haque, Ms. Nazma, and Ashfaque Ahmed. (2018). "LANDUSE AND LANDCOVER CHANGES AND THEIR GEO-ENVIRONMENTAL IMPACTS IN NACHOLE UPAZILA UNDER CHAPAI-NAWABGANG DISTRICT OF BANGLADESH: A RS AND GIS APPROACH." International Journal of Research - Granthaalayah, 6(9), 351-355. https://doi.org/10.5281/zenodo.1451859. 


\section{Introduction}

The study area is situated in the Northwestern region of the country in between $24^{\circ} 38^{\prime}$ and $24^{\circ} 51^{\prime}$ north latitudes and in between $88^{\circ} 15^{\prime}$ and $88^{\circ} 21^{\prime}$ East longitudes. It is bounded by Gomastapur Upazila on the north-west, Nawabganj sadar Upazila on the south-west, Tanore Upazila on the South-East, Niamatpur Upazila on the north-east.

This study investigated the changes in land-use and land cover of Nachole Upazila of Chapai Nawabgongj district. Satellite images were analyzed to detect changes in land use and land-cover in the last 34 years in the Barind tract of Nachole Upazila of Bangladesh.

The increase of vegetation cover and changes in land use pattern has been investigated using remote sensing satellite data. The area is constituted by two major physiography i.e. Barind Tract and Ganges River Flood Plain. The Ganges flood plain soil is on the western side of the upazila covering $9 \%$ and the $91 \%$ of the area is occupied by Barind soil. The semi-arid drought prone region of Bangladesh is called the Barind tract. So, this region experiences extremes to the climatic condition of the rest of the country.

Rainfall is comparatively low in this region, with the long-term average being about 1,250 $\mathrm{mm}$ in the west and 2,000 $\mathrm{mm}$ in the northeast, occurring mainly from late April to October. With a variable rainfall and temperature ranging from $25^{\circ} \mathrm{C}$ to $35^{\circ} \mathrm{C}$ (regularly exceeding $40^{\circ} \mathrm{C}$ ) in the monsoon season, the area is considered semiarid and drought-prone. Annual average temperature: maximum $37.8^{\circ} \mathrm{C}$, minimum $11.2^{\circ} \mathrm{C}$; annual rainfall $1862 \mathrm{~mm}$. Although $55 \%$ of the Barind was forested in 1850, subsequent rapid population growth resulted in $70 \%$ of the land being converted to arable land by 1970 (Oweis and Hachum).

Table 1: Temperature, Rainfall, Humidity during the years 2008-2011 at Chapai Nawabgonj

\begin{tabular}{|l|l|l|l|l|}
\hline \multirow{2}{*}{ Years } & \multicolumn{2}{|l|}{ Temperature (Centigrade) } & \multirow{2}{*}{ Rainfall (millimeter) } & Humidity (\%) \\
\cline { 2 - 3 } & Maximum & Minimum & & \\
\hline 2008 & 36.2 & 9.4 & 1160 & 79.0 \\
\hline 2009 & 37.6 & 11.6 & 1076 & 77.0 \\
\hline 2010 & 38.3 & 9.4 & 567 & 55.8 \\
\hline 2011 & 22.6 & 8.6 & 1477 & 78.0 \\
\hline
\end{tabular}

\section{Method}

Remote sensing data was Geo-referenced to Transverse Mercator projection system using Linear Transformation Matrix with Nearest Neighborhood re-sampling method. Pre-processed data were classified using on Digitization technique. Land use changes were determined in the last 34 years from 1983 to 2016. Necessary bands into Satellite images were used for analysis of land use parameters for the specific requirements of the study (Figure 1). 


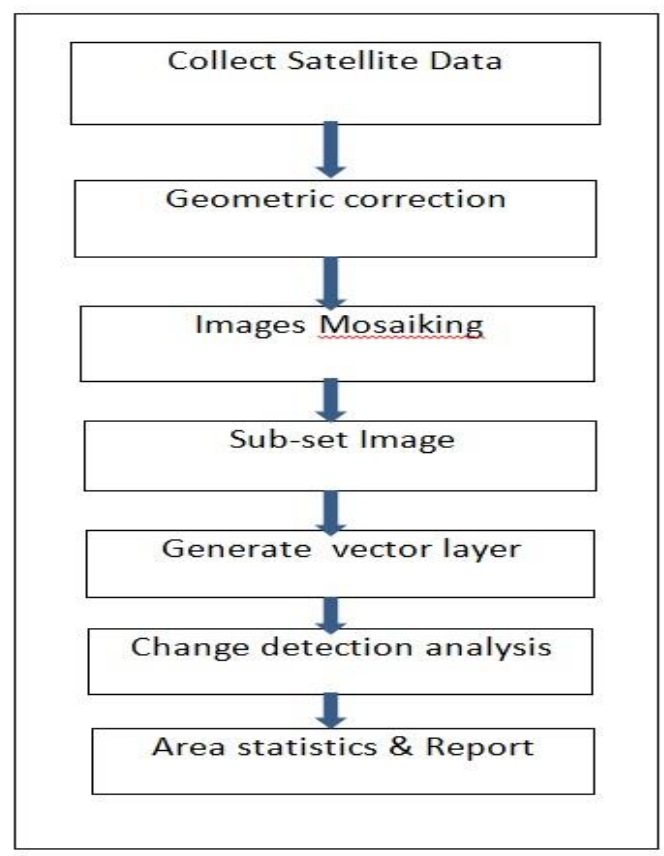

Figure 1: Flow Chart of Methodology used for processing images

For analysis the changing pattern of land use in Nachole Upazila and its geo-environmental impact, satellite images were analyzed to detect changes. The increase of vegetation cover and changes in land use pattern has been investigated using remote sensing digital images of IRC Aerial Photo 1983 and Google Image of 2016.

Figure 01 shows Image of 1983 (Aerial) and 2016 (Google) of Nachole Upazila. The drivers of land-use changes were explored in relation to their effects on social and ecological systems. Table 2 shows remote sensing data used in the present study. Figure 02 shows the landuse map of different year like Maps of 1983 (Aerial) and 2016 (Google) of Nachole Upazila.

Table 2: Remote sensing data used in the present study

\begin{tabular}{|l|l|l|l|}
\hline No & Types of Data & $\begin{array}{l}\text { Resolutio } \\
\text { n }\end{array}$ & Year \\
\hline 1. & Aerial IRC & $1 \mathrm{~m}$ & 1983 \\
\hline 3. & Google Image & $0.6 \mathrm{~m}$ & 2016 \\
\hline
\end{tabular}

\section{Results and Discussion}

This study investigated the changes in land-use in the past 34 years of Nachole Upazila Digital analysis give a picture of the significant changes in landuse pattern particularly in garden area. Table 03 shows Status of land-use parameter of Nachole Upazila. The data obtained from the Satellite image showed that in 1983, there were only 2,829.6 hectares of Garden area and in 2016; it is increased to 29,314.5 hectares. We found that Garden area in 2016 is more than ten times higher than that of in 1983. From the Image analysis we found water bodies area in 1983 was 9,358 hectares and in 2016 it is increased to $10,115.8$ hectares which is 757.8 hectares higher than that 
of in 1983. Again we found that settlement area is 18,374.1 hectares in 1983 and 23,680.9 hectares in 2016. So, settlement area increases between 1983 to 2016 is 5306.4 hectares.
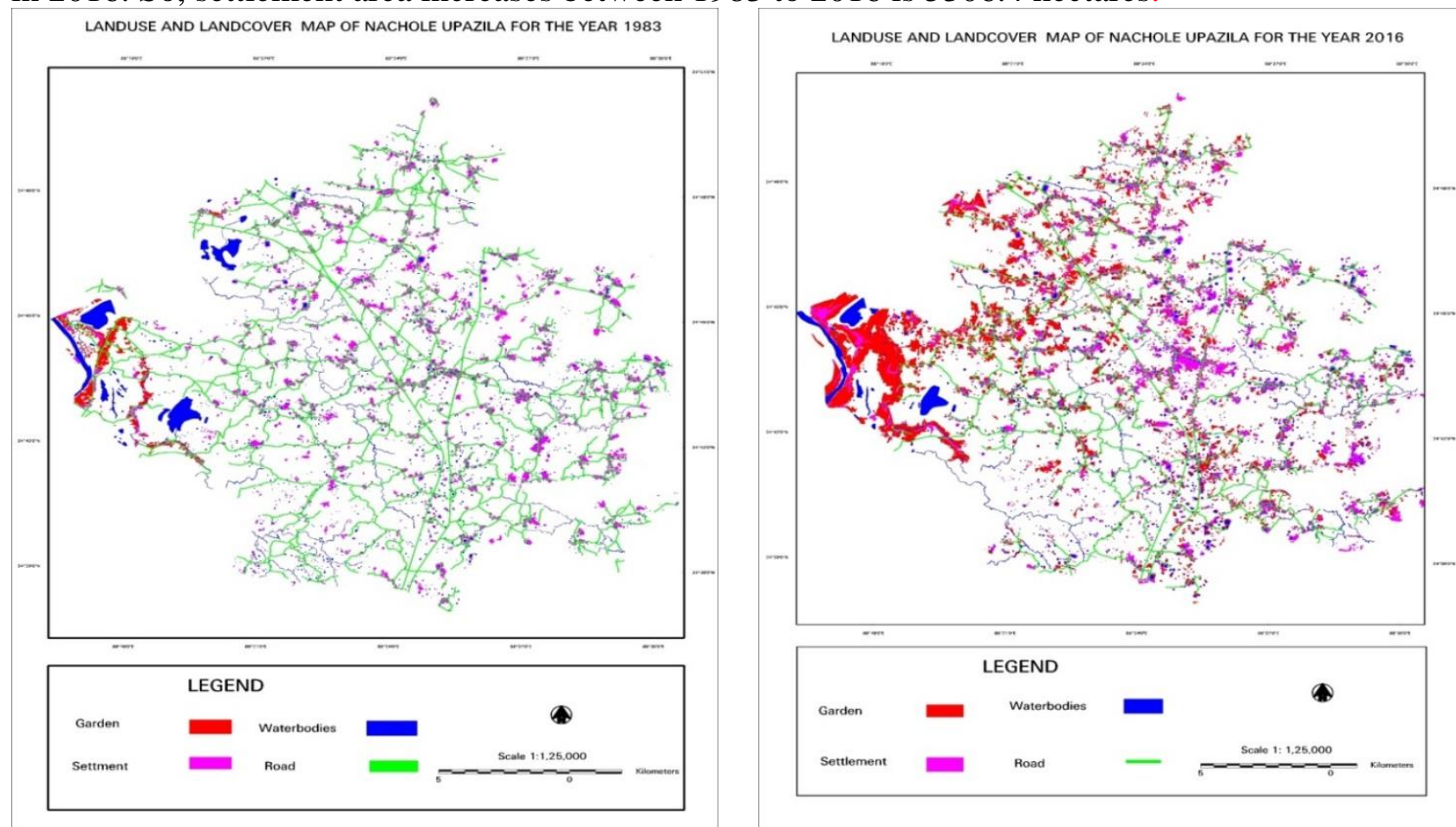

Figure 2: Land use and Land cover maps of 1983 (Aerial) and Landuse and Landcover maps of 2016 (Google) of Nacholeupazila;

Thus, from the investigation finally we found a garden area increases in 26,484.9 hectares, water bodies increase in 757.8 hectares and settlement area increases in 5306.4 hectares from 1983 to 2016. We also observed from the BBS report that mango, banana and other fruits cultivation area and production is in increasing trend.

Table 3: Status of land use parameter of Nachole Upazila of Chapai Nawabgong District

\begin{tabular}{|l|l|l|l|}
\hline \multirow{2}{*}{ Class Name } & \multicolumn{3}{|c|}{ Area in Hectares } \\
\cline { 2 - 4 } & Aerial Photo 1983 & Google Image 2016 & Area Increase Between the Year \\
\hline Garden & 2829.6 & $29,314.5$ & $26,484.9$ \\
\hline Settlement & $18,374.1$ & $23,680.9$ & 5306.4 \\
\hline Water bodies & 9358 & 10115.8 & 757.8 \\
\hline
\end{tabular}

Table 4: Area and production of Rice crops, Mango, and Banana 2009-2010, 2010-2011 (BBS report)

\begin{tabular}{|l|l|l|l|l|l|l|l|l|l|l|}
\hline Years & \multicolumn{2}{|l|}{ Mango } & \multicolumn{2}{|l|}{ Papaya } & \multicolumn{2}{l|}{ Guava } & \multicolumn{2}{l|}{ Jackfruit } & \multicolumn{2}{l|}{ Banana } \\
\cline { 2 - 9 } & $\begin{array}{l}\text { Are } \\
\text { a } \\
\text { Acr } \\
\text { e }\end{array}$ & $\begin{array}{l}\text { Produ } \\
\text { ction } \\
\text { (Ton) }\end{array}$ & Area & $\begin{array}{l}\text { Produ } \\
\text { ction }\end{array}$ & Area & $\begin{array}{l}\text { Prod } \\
\text { uctio } \\
\text { n }\end{array}$ & $\begin{array}{l}\text { Area } \\
\text { uctio } \\
\text { nod }\end{array}$ & $\begin{array}{l}\text { Area } \\
\text { ction }\end{array}$ \\
\hline $\begin{array}{l}2009- \\
2010\end{array}$ & 145 & 4335 & 21 & 147 & 17 & 156 & 06 & 44 & 47 & 293 \\
\hline
\end{tabular}




\begin{tabular}{|l|l|l|l|l|l|l|l|l|l|l|}
\hline $\begin{array}{l}2010- \\
2011\end{array}$ & 162 & 4410 & 24 & 170 & 19 & 151 & 08 & 57 & 57 & 354 \\
\hline
\end{tabular}

\section{Conclusion}

The present study established the appropriate application of Remote Sensing and GIS techniques for identification and evaluation of land use parameters in Nachole Upazila. From this study, it was observed that the land use pattern has been changed in Nachole Upazila. Garden and the waterbodies area have been increased. We know Garden and water bodies are very important elements of Natural environment and they have a big role in keeping balance of environment and ecosystem. So, from the finding of the research increased of area in garden and water bodies will enrich the natural environment and ecosystem of Nachole Upazila.

The Livelihood of the farmers has improved through the intervention of modern agricultural technologies, utilization of homestead areas, and plantation of fruit trees, etc. The results of this study will be helpful for the sustainable development and management of the uncontrolled and unplanned use of natural resources in Nachole Upazila. Control of resources, proper plan, and management of human activities (Unplanned settlement, land use, Deforestation and underground water use) can enhance the way to execute sustainable development and management (Riches, 2008).

\section{References}

[1] Bangladesh Population Census (2001). Bangladesh Bureau of Statistics: Cultural Survey Report of Nachole Upazila 2007.

[2] District Statistics (2011). Published in December, 2013, Published by: Bangladesh Bureau of Statistics (BBS).

[3] Food and Agriculture Organization (FAO) of the United Nations, Department of Agricultural Extension, Bangladesh (Title: Final Report- Study on livelihood systems assessment, vulnerable groups and livelihood adaptation to climate hazard and long term climate change in drought prone areas of NW Bangladesh).

[4] International Journal of Sustainable Water and Environmental Systems- A Case Study of Grid Connected Solar PV Irrigation System in Semi-Arid Region of Bangladesh. VL-1.

[5] Oweis, T., and Hachum, A. (2003). Improving water productivity in the dry areas of West Asia and North Africa. Water Productivity in Agriculture: Limits and Opportunities for Improvement. Edited by: Kijne JW, Barker R, Molden DJ. 2003, 179-198. Wallingford, UK: CABI.

[6] Rahamn, H., and Rahma, S. N. (2007). International Journal of Remote Sensing, 28(5),

[7] Riches, C. R. (2008). The High Barind Tract: a challenging drought-prone agricultural environment. In: Riches, C.R., Harris, D., Johnson, D.E. and Hardy, B., (Eds.) Improving agricultural productivity in rice-based systems of the High Barind Tract of Bangladesh. International Rice Research Institute, Los Baños (Philippines), pp. 3-6. ISBN 978-971-22-0229-2.

*Corresponding author.

E-mail address: shopanali65@yahoo.com/chamely02@yahoo.com/asoke_saha@yahoo.com 